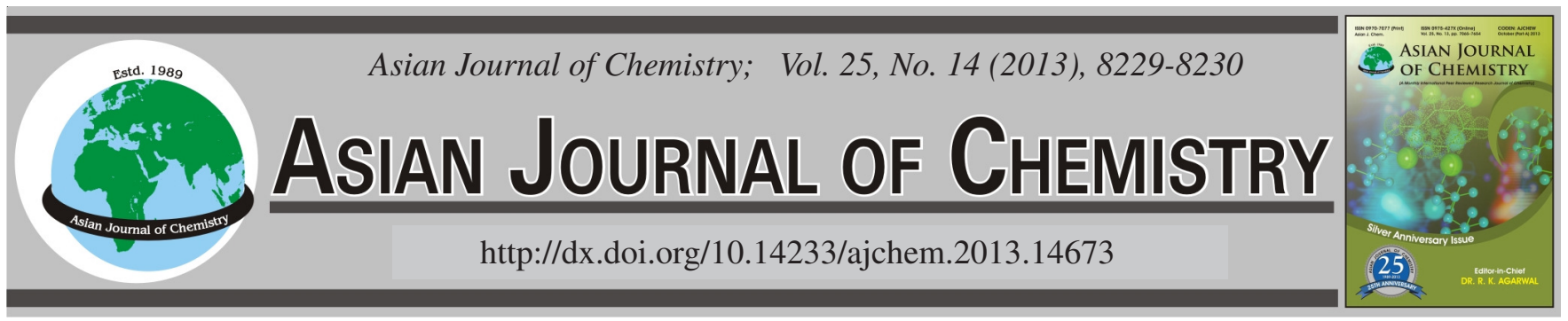

\title{
NOTE
}

\section{Study on Novel Structure of Potassium Piperazine Complex: $\mathrm{C}_{4} \mathrm{H}_{10} \mathrm{~N}_{2} \mathrm{~K}_{3} \mathrm{O}_{2}$}

\author{
Hai-Xing Liu ${ }^{1, *}$, Jing-Zhong Xiao ${ }^{2}$, Huan-Mei Guo ${ }^{1}$, KaI-Qi Ye$^{3}$, Guang Zeng ${ }^{3}$ and Xi-Shi Tai ${ }^{1}$
}

${ }^{1}$ Chemistry and Chemical and Environmental Engineering College, Weifang University, Weifang 261061, P.R. China
${ }^{2}$ CEMDRX, Department of Physics, University of Coimbra, Coimbra 3004-516, Portugal
${ }^{3}$ State Key Laboratory of Inorganic Synthesis and Preparative Chemistry, College of Chemistry, Jilin University, Changchun 130012, P.R. China

*Corresponding author: E-mail: haixingliu@ tom.com

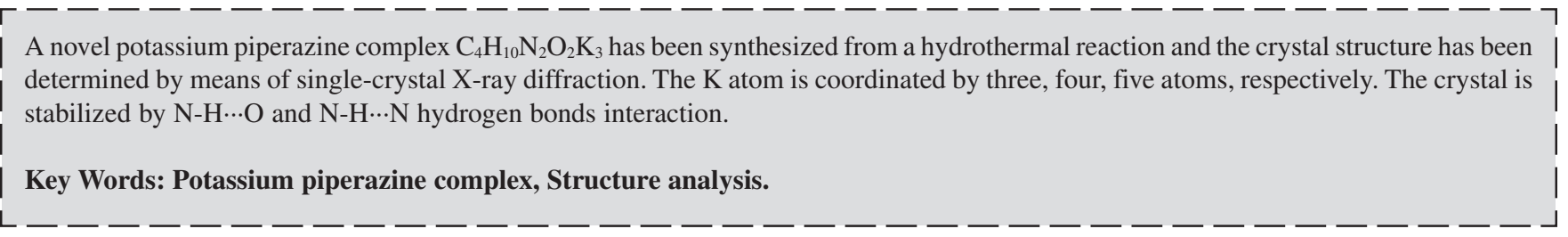

The polymers containing ligand groups can bind metal ions forming polymer-metal complexes ${ }^{1}$. The metal-complexes, which have a free coordination site or a weak ligand, can also coordinate with the polymers. The ionic complexes can also form ionic compounds with the polymer acting as counter ion. The interaction of the piperazine ring and its derivatives with metal ions have been extensively studied in solid state $^{2-5}$. In these compounds the piperazine group takes the chair conformation which is the most stable. $N, N^{\prime}$-disubstituted piperazines have found application as ligands in metal complexes and form the basis of various natural products that exhibit favourable pharmacological properties. Piperazine is conveniently substituted at the $N$ and $N^{\prime}$ positions via reductive amination and nucleophilic substitution reactions ${ }^{6}$. Piperazine and substituted piperazine derivatives have been found to possess diverse biological activities like antimicrobial, antiplasmodial, anti-inflammatory, antioxidant and antipsychotic activity $^{7-9}$. In this paper, the novel potassium piperazine complex is reported.

All commercially obtained reagent-grade chemicals were used without further purification. A mixture of $\mathrm{Ho}_{2} \mathrm{O}_{3}(0.01$ mmol, $0.004 \mathrm{~g})$, dilute $\mathrm{HNO}_{3}, \mathrm{KCl}(0.1 \mathrm{mmol}, 0.008 \mathrm{~g})$, piperazine $(0.1 \mathrm{mmol}, 0.016 \mathrm{~g})$ and boric acid $(0.1 \mathrm{mmol}, 0.009$ g) were added into $20 \mathrm{~mL}$ water with $10 \%$ (v/v) ethanol and heated for $5 \mathrm{~h}$ at $413 \mathrm{~K}$. The solution was obtained by filtration after cooling the reaction to room temperature. Colourless block single crystals suitable for X-ray measurements were obtained after a few weeks.
The crystal structure of potassium piperazine complex (Fig. 1) is built up of $\mathrm{K}$ atom, $\mathrm{O}$ atom and piperazine. The crystal data and structure refinement is shown in Table-1. The $\mathrm{K} 1$ atom is coordinated by three $\mathrm{O}$ atoms (two $\mathrm{O} 1$, one $\mathrm{O} 2$ ). The $\mathrm{K} 2$ atom is coordinated by two $\mathrm{O} 1$ atoms and two N1 atoms from piperazine. The $\mathrm{K} 3$ atom is coordinated by two $\mathrm{O} 1$ atoms, two $\mathrm{N} 1$ atoms and one $\mathrm{O} 2$ atom. The four atoms (K1, O1, K3, O2) are in the same plane. The distance between two parallel planes is $6.429 \AA$. The distances $\mathrm{d}(\mathrm{K}-\mathrm{O})$ are in the range of 3.04-3.43 $\AA$. The distances $\mathrm{d}(\mathrm{K}-\mathrm{N})$ are in the range of 3.192-3.397 $\AA$. The O1 atom, O2 atom, K1 atom and K3 atom are located in the equatorial plane. The bond angles of O1-K2-O1, N1-K3-N1 are 80.27 and $89.82^{\circ}$, respectively. Selected bond lengths and bond angles are shown in Table- 2 .

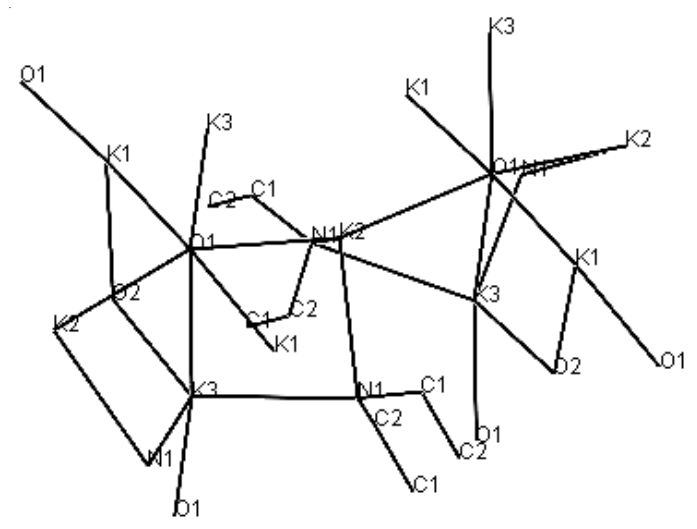

Fig. 1. Molecular structure of the title complex 


\begin{tabular}{|c|c|}
\hline \multicolumn{2}{|c|}{$\begin{array}{c}\text { TABLE-1 } \\
\text { CRYSTAL DATA AND STRUCTURE REFINEMENT } \\
\text { FOR THE POTASSIUM PIPERAZINE COMPLEX }\end{array}$} \\
\hline Empirical formula & $\mathrm{C}_{4} \mathrm{H}_{10} \mathrm{~N}_{2} \mathrm{O}_{2} \mathrm{~K}_{3}$ \\
\hline Formula weight & 235.44 \\
\hline Temperature & $273(2) \mathrm{K}$ \\
\hline Wavelength & $0.71073 \AA$ \\
\hline Crystal system, space group & Orthorhombic, $\mathrm{Pbcm}$ \\
\hline Unit cell dimensions & $\begin{array}{lll}\mathrm{a}=6.5081(5) \AA & \alpha=90^{\circ} \\
\mathrm{b}=12.8580(8) \AA & \beta=90^{\circ} \\
\mathrm{c}=12.8580(9) \AA & \gamma=90^{\circ}\end{array}$ \\
\hline Volume & $1075.97(13) \AA^{3}$ \\
\hline Z, Calculated density & $4,1.453 \mathrm{Mg} / \mathrm{m}^{3}$ \\
\hline Absorption coefficient & $1.229 \mathrm{~mm}^{-1}$ \\
\hline $\mathrm{F}(000)$ & 484 \\
\hline Crystal size & $0.45 \times 0.44 \times 0.41 \mathrm{~mm}$ \\
\hline Theta range for data collection & 3.13 to $24.99^{\circ}$ \\
\hline Limiting indices & $\begin{array}{l}-7<=\mathrm{h}<=7,-14<=\mathrm{k}<=15,-15 \\
<=1<=15\end{array}$ \\
\hline Reflections collected/unique & $10484 / 998[\mathrm{R}(\mathrm{int})=0.0354]$ \\
\hline Completeness to $\theta=26$ & $100 \%$ \\
\hline Absorption correction & Semi-empirical from equivalents \\
\hline Max and min transmission & 0.6327 and 0.6077 \\
\hline Refinement method & Full-matrix least-squares on $\mathrm{F}^{2}$ \\
\hline Data/restraints/parameters & $998 / 0 / 58$ \\
\hline Goodness-of-fit on $\mathrm{F}^{2}$ & 1.192 \\
\hline Final $R$ indices $[\mathrm{I}>2 \sigma(\mathrm{I})]$ & $\mathrm{R} 1=0.0518, \mathrm{wR} 2=0.1839$ \\
\hline $\mathrm{R}$ indices (all data) & $\mathrm{R} 1=0.0550, \mathrm{wR} 2=0.1873$ \\
\hline Extinction coefficient & $0.010(3)$ \\
\hline Largest diff. peak and hole & 0.874 and -0.718 e. $\AA^{-3}$ \\
\hline
\end{tabular}

TABLE-1

PIPERAZINE COMP

TABLE-2

SELECT BOND LENGTHS [^̊] AND ANGLES $\left[^{\circ}\right]$ FOR THE POTASSIUM PIPERAZINE COMPLEX

\begin{tabular}{|c|c|c|c|}
\hline \multicolumn{4}{|c|}{$\begin{array}{c}\text { TABLE-2 } \\
\text { SELECT BOND LENGTHS [^] AND ANGLES }\left[^{\circ}\right] \text { FOR } \\
\text { THE POTASSIUM PIPERAZINE COMPLEX }\end{array}$} \\
\hline $\mathrm{K}(1)-\mathrm{O}(2)$ & $3.070(4)$ & $\mathrm{O}(2)-\mathrm{K}(3)-\mathrm{N}(1)$ & $131.00(7)$ \\
\hline $\mathrm{K}(1)-\mathrm{O}(1)$ & $3.201(5)$ & $\mathrm{N}(1)-\mathrm{K}(3)-\mathrm{O}(1)$ & $82.66(9)$ \\
\hline $\mathrm{K}(2)-\mathrm{N}(1)$ & $3.192(3)$ & $\mathrm{O}(2)-\mathrm{K}(3)-\mathrm{K}(2)$ & $85.65(6)$ \\
\hline $\mathrm{K}(2)-\mathrm{O}(1)$ & $3.2931(12)$ & $N(1)-K(3)-K(2)$ & $48.57(6)$ \\
\hline $\mathrm{K}(3)-\mathrm{O}(2)$ & $3.040(4)$ & $\mathrm{O}(1)-\mathrm{K}(3)-\mathrm{K}(2)$ & $50.28(2)$ \\
\hline $\mathrm{K}(3)-\mathrm{N}(1)$ & $3.340(3)$ & $\mathrm{O}(2)-\mathrm{K}(3)-\mathrm{K}(1)$ & $37.41(8)$ \\
\hline $\mathrm{K}(3)-\mathrm{O}(1)$ & $3.354(6)$ & $\mathrm{N}(1)-\mathrm{K}(3)-\mathrm{K}(1)$ & $111.05(6)$ \\
\hline $\mathrm{N}(1)-\mathrm{C}(2)$ & $1.484(5)$ & $\mathrm{O}(1)-\mathrm{K}(3)-\mathrm{K}(1)$ & $40.87(9)$ \\
\hline $\mathrm{N}(1)-\mathrm{C}(1)$ & $1.488(5)$ & $K(2)-K(3)-K(1)$ & $63.44(2)$ \\
\hline $\mathrm{O}(2)-\mathrm{H}(2)$ & 0.8500 & $\mathrm{C}(2)-\mathrm{N}(1)-\mathrm{C}(1)$ & $110.7(3)$ \\
\hline $\mathrm{C}(1)-\mathrm{H}(1 \mathrm{~A})$ & 0.9700 & $\mathrm{C}(2)-\mathrm{N}(1)-\mathrm{K}(2)$ & $99.0(2)$ \\
\hline $\mathrm{O}(2)-\mathrm{K}(1)-\mathrm{O}(1)$ & $80.27(12)$ & $\mathrm{C}(1)-\mathrm{N}(1)-\mathrm{K}(2)$ & $97.8(2)$ \\
\hline $\mathrm{O}(2)-\mathrm{K}(1)-\mathrm{K}(2)$ & $75.11(6)$ & $\mathrm{C}(2)-\mathrm{N}(1)-\mathrm{K}(3)$ & $87.9(2)$ \\
\hline $\mathrm{O}(1)-\mathrm{K}(1)-\mathrm{K}(2)$ & $43.14(2)$ & $\mathrm{C}(1)-\mathrm{N}(1)-\mathrm{K}(3)$ & $161.5(2)$ \\
\hline $\mathrm{N}(1)-\mathrm{K}(2)-\mathrm{O}(1)$ & $85.93(11)$ & $\mathrm{K}(2)-\mathrm{N}(1)-\mathrm{K}(3)$ & $79.76(7)$ \\
\hline $\mathrm{N}(1)-\mathrm{K}(2)-\mathrm{K}(3)$ & $51.67(6)$ & $\mathrm{K}(1)-\mathrm{O}(1)-\mathrm{K}(2)$ & $95.20(10)$ \\
\hline $\mathrm{O}(1)-\mathrm{K}(2)-\mathrm{K}(3)$ & $51.58(9)$ & $\mathrm{K}(2)-\mathrm{O}(1)-\mathrm{K}(3)$ & $78.13(9)$ \\
\hline $\mathrm{N}(1)-\mathrm{K}(2)-\mathrm{K}(1)$ & $115.80(6)$ & $\mathrm{K}(1)-\mathrm{O}(2)-\mathrm{H}(2)$ & 110.6 \\
\hline $\mathrm{O}(1)-\mathrm{K}(2)-\mathrm{K}(1)$ & $41.66(9)$ & $\mathrm{N}(1)-\mathrm{C}(1)-\mathrm{H}(1 \mathrm{~A})$ & 109.3 \\
\hline $\mathrm{K}(3)-\mathrm{K}(2)-\mathrm{K}(1)$ & $65.18(2)$ & $\mathrm{H}(1 \mathrm{~A})-\mathrm{C}(1)-\mathrm{H}(1 \mathrm{~B})$ & 108.0 \\
\hline
\end{tabular}

\section{ACKNOWLEDGEMENTS}

This study were supported by the Natural Science Foundation of Shandong Province (No. ZR2010BL025), State Key Laboratory of Inorganic Synthesis and Preparative Chemistry (Jilin University) (No. 2011-13), MOE Key Laboratory of Analytical Chemistry for Life Science (Nanjing University) (No. KLACLS1002) and the National Science Foundation of China (No. 21171132) and Open Project of State Key Laboratory of Supramolecular Structure and Materials (No. sklssm201323) (Jilin University).

\section{REFERENCES}

1. B.L. Rivas and G.Y. Seguel, J. Appl. Polym. Sci., 85, 2546 (2002).

2. D.A. Cleinente, A. Marrotto, G.C. Valle and C.J. Visona, Polyhedron, 18, 2749 (1999).

3. A. Marrotto, D.A. Clemente, F. Benetollo and G.C. Valle, Polyhedron, 20, 171 (2001).

4. A. Ciccarese, D.A. Clemente, F.P. Fanizzi, A. Marrotto and G. Valle, Inorg. Chim. Acta, 419, 275 (1998).

5. G.V. Seguel and B.L. Rivas, Polym Bull., 51, 39 (2003).

6. J.P. Safko and R.D. Pike, J. Chem. Crystallogr, 42, 981(2012).

7. S.G. Shingade and S.B. Bari, Med. Chem. Res., 22, 699 (2012).

8. E. Yoo, J. Yoon, A.N. Pae, H. Rhim, W. Park, J.Y. Kong and H.P. Choo, Biol. Med. Chem., 18, 1665 (2010).

9. S.-R. Chen, A.-J. Li and M.-M. Chen, Asian J. Chem., 24, 1680 (2012). 